\title{
Evaluation of different marking methods for spiny-cheek crayfish (Orconectes limosus)
}

\author{
M. Buřič, P. Kozák, P. Vích \\ Received August 12, 2008 / Reçu le 12 août 2008 \\ Accepted August 19, 2008 / Accepté le 19 août 2008
}

Key-words: Different methods of marking were evaluated for Orconectes limosus crayfish, Orconectes limosus, marking, moult increment

\section{ABSTRACT} ( $\mathrm{CL}=$ carapace length, $12-37 \mathrm{~mm}$ ) under laboratory conditions: the use of passive integrated transponders, visible implant elastomers, visible implant alphanumeric tags, and cauterization. High survival (> 90\%) was obtained with all methods tested. Tag retention and readability were evaluated immediately after marking, before and after ecdysis, with moult increments and number of moults been recorded. Marking using cauterization negatively affects the percent moult increment (PMI) of crayfish. The average PMI of $15 \pm 0.88 \%$ did not differ between males $(15 \pm 1.41 \mathrm{~mm})$ and females $(15 \pm 1.12 \mathrm{~mm})$. It was found that PMI gradually decreased with an increase in CL. Sixty-one moults were observed, with 12 crayfish ( 6 juveniles and 6 adults) presenting two moults. Time between moults varied from 3 to 7 weeks. CL was increased with over $28 \pm 2.68 \%$ due to two moults. Three females moulted twice after successful hatching and carrying of juveniles.

RÉSUMÉ

\section{Évaluation de différentes méthodes de marquage d'une écrevisse américaine (Orconectes limosus)}

Mots-clés : écrevisse, Orconectes limosus, marquage, incrément
Différentes méthodes de marquage ont été évaluées pour Orconectes limosus ( $C L$ = la taille de la carapace, $12-37 \mathrm{~mm}$ ) dans des conditions de laboratoire : l'usage des transpondeurs intégrés passifs, les élastomères implantés visibles, les étiquettes visibles alphanumériques implantées et une cautérisation. Une survie élevée (> $90 \%$ ) a été obtenue avec toutes les méthodes testées. Rétention d'une étiquette et lisibilité ont été appréciées toute de suite après un marquage, avant et après une mue, des incréments d'une mue et un nombre des mues ayant été notés. Un marquage utilisant la cautérisation influence négativement l'accroissement relatif à chaque mue $(\mathrm{PMI})$. Le $\mathrm{PMI}$ moyen de $15 \pm 0.88 \% \mathrm{n}$ 'a pas varié entre les mâles $(15 \pm 1.41 \mathrm{~mm})$ et les femelles $(15 \pm 1.12 \mathrm{~mm})$. On a trouvé que le PMl a graduellement diminué avec une augmentation de CL. Soixante et une mues ont été observées, avec 12 écrevisses (6 juvéniles et 6 adultes) qui présentent deux mues. Le temps entre les mues a varié de 3 à 7 semaines. Le CL était augmenté avec plus de $28 \pm 2.68 \%$, dû aux deux mues. Trois femelles ont mué deux fois après une éclosion réussie et un transport des juvéniles. 


\section{INTRODUCTION}

Orconectes limosus (Rafinesque, 1817), a temperate-water crayfish native of north eastern USA and south-eastern Canada, shows tolerance to organic-rich waters and general pollutants. Although it occurs in rivers, its preferred habitats as ponds and lakes (Hamr, 2002). The first successful introduction into Europe took place in 1890 when some specimens were stocked into a fishpond in Barnowko (Poland). Further introductions in France and successful secondary introductions in many European water-bodies, combined with natural dispersal, has resulted in its presence in several European countries (Henttonen and Huner, 1999; Holdich et al., 2006), including Czech Republic (Petrusek et al., 2006).

$O$. limosus is a fast spreading, crayfish plague carrying, invasive species, which poses a serious threat to indigenous crayfish (Henttonen and Huner, 1999; Holdich and Black, 2007). Early maturation (Holdich et al., 2006), high fecundity (Stucki, 2002), fast growth (Kozák et al., 2007), and a short life span (Holdich et al., 2006), suggest that $O$. limosus is a r-selected species (Henttonen and Huner, 1999). More moults, in contrast to moult increments, resulted in faster growth in crayfish (Lowery, 1988). However, similar to noble crayfish Astacus astacus (Skurdal and Taugbøl, 2002), adult $O$. limosus usually moult once (ovigerous females) or twice (males, females) per year (Holdich and Black, 2007).

Despite the fact that $O$. limosus is one of the largest macroinvertebrates in several American and European freshwater water-bodies, and its wide distribution and invasiveness, the ecology of this species was less studied. In order to obtain information on population dynamics a suitable observation method, which does not influence survival, growth and behaviour, is crucial. Mark and recapture methods are widely used in field (Abrahamsson, 1973; Guan, 1997; Bubb et al., 2002) and laboratory (Guan and Wiles, 1996; Barki et al., 1997; Kuhlmann et al., 2008) experiments on crayfish.

Objectives of the present study were: (1) to evaluate four different marking methods for $O$. limosus (tag retention and readability, effects of tagging on survival); (2) to evaluate the effect of tagging on moult increments, and to observe the relationship with number of moults.

\section{MATERIAL AND METHODS}

\section{$>$ CRAYFISH}

O. limosus specimens were captured (in overall 155 pcs.) in the brook 'Pšovka' in central Czech Republic during the beginning of April 2007. Crayfish were acclimated to laboratory conditions for 14 days before tagging. Total length (TL; from tip of the rostrum to the posterior median edge of the telson) and carapace length ( $\mathrm{CL}$; from the tip of the rostrum to the posterior median edge of the cephalothorax) were measured to the nearest $1 \mathrm{~mm}$ with vernier calipers, and wet body weight of crayfish to the nearest $0.01 \mathrm{~g}$ with an electronic balance (Kern \& Sohn GmbH, Balingen, Germany). Average TL and CL of crayfish used were $53.5 \pm 13.83 \mathrm{~mm}$ and $24.9 \pm 0.69 \mathrm{~mm}$, respectively, with an average body weight of $6.2 \pm$ $0.4 \mathrm{~g}$. Crayfish were partitioned into five groups (20 crayfish in each group with sex ratio 1:1) according to treatment. There was not significant difference between groups in size.

\section{$>$ MARKING}

\section{Passive integrated transponders (PITs)}

Crayfish were tagged with PIT tags of $12 \times 2.1 \mathrm{~mm}$ in size and 0.1 in weight. Animals were held around the cephalothorax with the ventral surface upwards, and an incision of ca. $3 \mathrm{~mm}$ wide and deep was made through the cuticle and abdominal musculature of the third abdominal segment with the tip of a sterile large (diameter $2.5 \mathrm{~mm}$ ) hypodermic needle. 

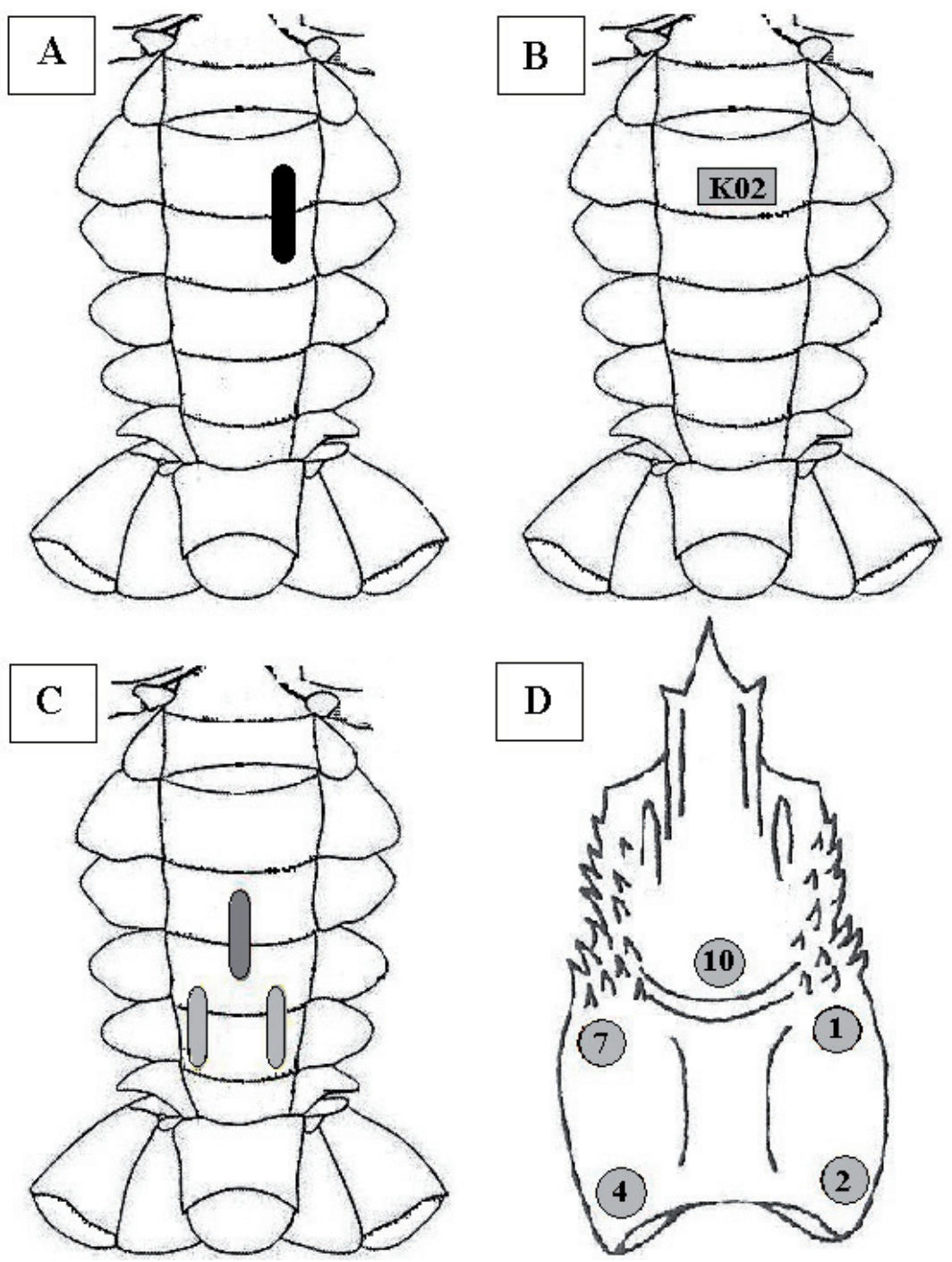

\section{Figure 1}

Position of tags. A - Passive integrated transponder inserted in abdominal musculature. $B$ - Position of visible implant alphanumeric tag under transparent ventral abdominal cuticle. C - Location of individual marks made by visible implant elastomers under transparent ventral abdominal cuticle. D - System for numerical marking of crayfish using cauterization.

\section{Figure 1}

Position des marques. A - Transpondeur passif inséré dans la musculature abdominale. B - Position d'une étiquette alphanumérique intégrée sous une cuticule abdominale ventrale transparente. C Localisation des marques spécifiques créées par les élastomères visibles implantés sous une cuticule abdominale ventrale transparente. D - Système de marquage des écrevisses utilisant une cautérisation.

The tag was inserted through the incision by gently pushing the tag anteriorally to fit between the edge of abdomen and hindgut (Figure 1A). After tagging the number of the PIT was read on a portable reader (Datamars S.A., Lugano, Switzerland).

\section{Visible implant alphanumeric tags (VI Alpha tags)}

VI Alpha tags of $2.5 \times 1 \mathrm{~mm}$, made from soft plastic (Northwest Marine Technology ${ }^{\top M}$, Shaw Island, USA), were used. Tagging at the third abdominal segment was carried out similarly 
as for PITs using the tip of the injector. The tag was inserted through the incision by gently pushing it with the rod of the injector (Figure 1B), whereafter the injector was slowly withdrawn.

\section{Visible implant elastomers (elastomers)}

After thorough mixing of the two elastomer components in equal parts it was loaded into an injection syringe (Northwest Marine Technology ${ }^{T M}$, Shaw Island, USA). Tagging was done as described above with a syringe needle inserted into the marking location (Figure 1C). When a long narrow mark was created the injector was slowly withdrawn. It is important that the tag created is fully complete on the target tissue; extrusion of the material from the needle must cease before the needle is withdrawn so that material does not project through the needle wound; this is likely to cause rapid loss of the tag.

\section{Cauterization}

Crayfish were marked with a portable gas soldering iron (Ferm, Zwolle, Netherlands) by touching the carapace for a few seconds to create red-orange spots on the cuticle, which were visible after moulting as white spots. A modified system for numerical marking of crayfish (Abrahamsson, 1973), with the use of five number marks (Figure 1D), was applied.

\section{$>$ EXPERIMENTAL CONDITIONS}

The study was conducted between 19 April and 28 June 2007 over a 70 day period in Vodňany. Groups of marked crayfish were kept in 5 circular tanks with a volume of $0.12 \mathrm{~m}^{3}$ and diameter of $0.6 \mathrm{~m}$ supplied with shelters. Tag retention, readability, survival and number of moults were determined on a weekly basis, and moult increments were measured with vernier calliper. Tanks were regularly cleaned, with water temperature similar to outdoor water temperature. Water temperature was measured every $3 \mathrm{~h}$ using data loggers (RT-F53, Qi Analytical, Prague, Czech Republic), and dissolved oxygen level twice daily. Crayfish were fed on frozen chironomid larvae and fish meat three times per week.

\section{> STATISTICAL ANALYSIS}

T-tests were used to compare moult increments between males and females, and between successive $\left(1^{\text {st }}\right.$ and $\left.2^{\text {nd }}\right)$ moults. Data for survival and increments in particular groups were analysed by the non-parametric Kruskal-Wallis test. Spearman rank correlation was used to determine the relationship between percent moult increment (PMI) and CL. The null hypothesis was rejected at $\alpha=0.05$. Data are presented as average \pm standard error of mean. For data analysis was used program Statistica 7.0 (StatSoft, Inc.).

\section{RESULTS}

\section{> EVALUATION OF MARKING METHODS}

Most of the injuries on the cuticle caused by tagging were cured within a few days. All methods evaluated were found suitable for tagging of $O$. limosus. Very small crayfish (13-14 mm CL) were successfully marked by VI Alpha tags and elastomers. Survival did not differ $(H=5.699 ; P=0.223)$ among marking methods (Figure 2$)$. Mortality mainly occurred during the time when crayfish moulted. All groups showed a high survival rate.

High retention and readability of all type of tags were found (Table I). The spots after cauterization appeared well grown over after moult, which led to more difficult readability. Although VI Alpha tags before and after moult presented high readability, several tags were 


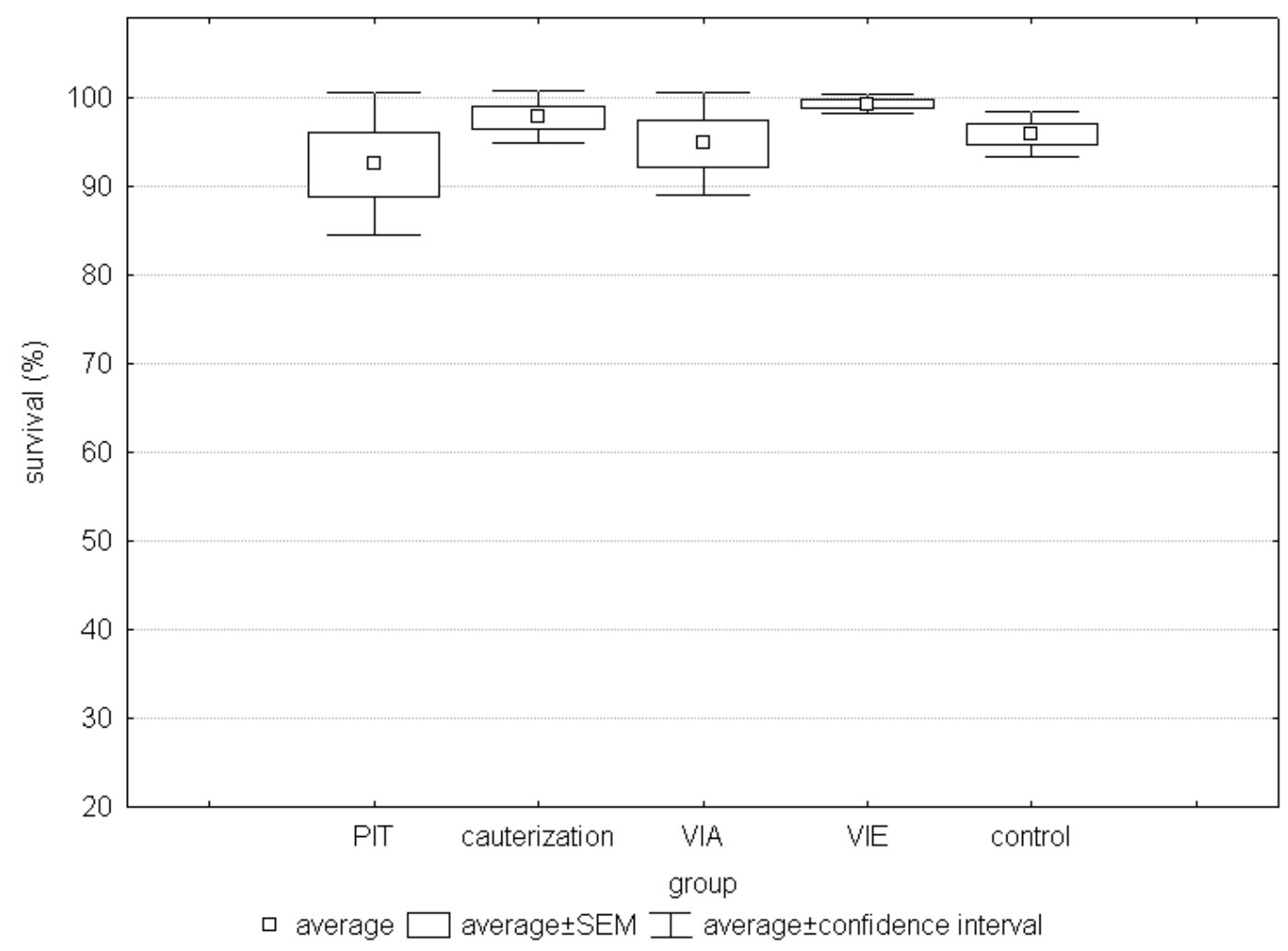

\section{Figure 2}

Survival of crayfish in particular experimental groups (Kruskal-Wallis test; $H=5.699 ; P=$ 0.223). VIA: visible implant alphanumeric; VIE: visible implant elastomers.

\section{Figure 2}

Survie des écrevisses dans les groupes expérimentaux spécifiques (Kruskal-Wallis test ; $H=5.699 ; P=$ 0.223). VIA : implant visible alphanumérique ; VIE : élastomères visibles implantés.

\section{Table I}

Percentage of readable marks before and after moulting and tag retention as influenced by different marking methods.

Tableau I

Pourcentage de marques lisibles avant et après la mue et de rétention des étiquettes, pour les différentes méthodes de marquage.

\begin{tabular}{|l|c|c|c|}
\hline \multirow{2}{*}{ Marking method } & \multicolumn{2}{|c|}{ Readability (\%) } & Tag retention \\
\cline { 2 - 4 } & Before moult & After moult & $(\%)$ \\
\hline PITs & 100 & 100 & 100 \\
\hline Cauterization & 100 & 80 & 100 \\
\hline VI Alpha tags & 100 & 100 & 85 \\
\hline VI elastomers & 80 & 80 & 100 \\
\hline
\end{tabular}


lost in this group. The slow setting and smudging of elastomers caused the impaired readability, but moulting did not affect further changes.

\section{> MOULT INCREMENTS AND NUMBER OF MOULTS}

The average total moult increment and percentage moult increment (PMI) of CL was found as $3 \pm 0.15 \mathrm{~mm}$ and $15 \pm 0.88 \%$, respectively. Average total increments did not differ $(t=$ 1.325; $P=0.191)$ between males $(3.2 \pm 0.21 \mathrm{~mm})$ and females $(2.8 \pm 0.19 \mathrm{~mm})$. This was also illustrated $(t=-0.01 ; P=0.994)$ in PMl, with values of $15 \pm 1.41$ and $15 \pm 1.12 \mathrm{~mm}$ for males and females, respectively. With an increase in CL the PMI gradually decreased (Spearman rank correlation, $r_{\mathrm{s}}=-0.617, P<0.05$ ). This trend was also observed within sex (Spearman rank correlation, males, $r_{\mathrm{s}}=-0.683, P<0.05$; females, $\left.r_{\mathrm{s}}=-0.551, P<0.05\right)$. PMI values of $13.9 \pm 1.73 \%, 17.7 \pm 1.74 \%$ and $14.9 \pm 0.99 \%$ were obtained for PITs, VI Alpha tag, and elastomer treatments, respectively, with a lower $(H=10.3 ; P=0.016)$ value $(9.7 \pm 1.26 \%)$ derived for the group marked by cauterization. However, CL of moulted crayfish did not differ $(H=3.01 ; P=0.221)$ among groups.

Sixty-one moults occurred during the experiment. Twelve crayfish ( 5 males, 7 females) moulted twice, with double moults observed in 6 juveniles ( 3 males, 3 females) and 6 adults ( 2 males, 4 females). Time between moults varied from 3 to 7 weeks. CL increased by over $28 \pm 2.68 \%$ due to two moults. Of four adult females three presented two successive moults in 3 to 4 weeks after successful hatching and carrying of juveniles. Three adult crayfish underwent two moults during a 4-6 week period. A significant difference $(t=3.01 ; P=0.011)$ between $\mathrm{PMI}$ in the $1^{\text {st }}(17.3 \pm 2.17 \%)$ and $2^{\text {nd }}(9.2 \pm 1.36 \%)$ moults was found.

\section{DISCUSSION}

All methods evaluated were found to be suitable for successful marking of $O$. limosus. Application of the different methods was simple and fast, fulfilling the requirement of creating minimum stress. Elastomers and VI Alpha tags were clearly visible through the ventral somites, were retained after moulting, and did not interfere with survival and growth. The above methods are preferred to other marking methods for crustaceans, because they allow long-term individual identification and the tagging of small size-class animals. Other tags such as external marks are often lost during moults (Gherardi et al., 2000), whereas use of internal transponders (Bubb et al., 2002) and cauterization are hampered by the size of the animal. In addition, with cauterization spots are visible for only ca. 2 moults (Abrahamsson, 1973). Other workers have found that cauterization spots can be seen for more than 2 moults. Marking by PITs is possible only for big adults (> $25 \mathrm{~mm} \mathrm{CL}$ ). On the other hand passive integrated transponders allowed fast and exact determining of marked crayfish. Marking of crayfish can negatively affect growth, e.g. external tags (Graaf, 2007) or punching holes in uropods and telson (Guan, 1997). Although the values of PMI in all experimental groups were high, the crayfish marked using cauterization had a significantly lower PMI than other groups, hence cauterization could not be recommended for study of growth in crayfish. VI Alpha tags are recommended as an effective inexpensive method to identify individual crayfish for long-term studies. On the other hand, several tags could be lost during moulting. The observed PMI of $O$. limosus is comparable to PMI of juvenile $A$. astacus in their first growing season (Ackefors et al., 1995), and higher than for juvenile Austropotamobius pallipes and Procambarus clarkii (5-10\%) (Paglianti and Gherardi, 2004). The present study presents evidence that three females which successfully hatched and carried juveniles, together with three other adults, were able to moult twice during one month. This is in contrast to the finding of Holdich and Black (2007) that adults of O. limosus usually moult once (ovigerous females) or twice (males) per year, but in agreement to results obtained for Orconectes neglectus chaenodactylus (Price and Payne, 1978). The short intermoult period probably lead to the lower PMI at second moult. Faster growth in O. limosus is attributed 
to a high PMI and moult frequency, because growth is accomplished as a product of moult increment and moult frequency (Reynolds, 2002). Fast growth contribute to the invasive success of $O$. limosus. A trend of a decrease in PMI with an increase in CL was found, in accordance to results obtained with P. leniusculus (Guan and Wiles, 1996; Buriič et al., 2007).

\section{ACKNOWLEDGEMENTS}

This investigation was financially supported by the Czech Ministry of Education (project USB RIFCH No. MSM6007665809) and the Czech Science Foundation (project GAAV IAA601870701).

\section{REFERENCES}

Abrahamsson S.A.A., 1973. The crayfish Astacus astacus in Sweden and the introduction of the American crayfish Pacifastacus leniusculus. Freshwater Crayfish, 1, 27-39.

Ackefors H., Gydemo R. and Keyser P., 1995. Growth and moulting in confined juvenile noble crayfish Astacus astacus (L.) (Decapoda, Astacidae). Freshwater Crayfish, 10, 396-409.

Barki A., Levi T., Hulata G. and Karplus I., 1997. Annual cycle of spawning and molting in the red-claw crayfish, Cherax quadricarinatus, under laboratory conditions. Aquaculture, 157, 239-249.

Bubb D.H., Lucas M.C., Thom T.J. and Rycroft P., 2002. The potential use of PIT telemetry for identifying and tracking crayfish in their natural environment. Hydrobiologia, 483, 225-230.

Burrič M., Kozák P., Kanta J., Kouba A. and Policar T., 2007. The effect of water temperature on number of moults and growth of juvenile signal crayfish (Pacifastacus leniusculus D.). Bulletin VúRH Vodňany, 43, 1, 16-26.

Gherardi F., Barbaresi S. and Salvi G., 2000. Spatial and temporal patterns in the movement of Procambarus clarkii, an invasive crayfish. Aquat. Sci., 62, 179-193.

Graaf M., 2007. Tag retention, survival and growth of marron Cherax tenuimanus (Crustacea: Decapoda) marked with coded micro wire tags. Mar. Freshw. Res., 58, 11, 1044-1047.

Guan R.Z., 1997. An improved method for marking crayfish. Crustaceana, 70, 641-652.

Guan R.Z. and Wiles P.R., 1996. Growth, density and biomass of crayfish, Pacifastacus leniusculus, in a British lowland river. Aquat. Living Resour., 9, 3, 265-272.

Hamr P., 2002. Orconectes. In: Holdich D.M. (ed.), Biology of Freshwater Crayfish, Blackwell Science Ltd., London, 585-608.

Henttonen P. and Huner J.V., 1999. The introduction of alien species of crayfish in Europe: A historical introduction. In: Gherardi F., Holdich D.M. (eds.), Crayfish in Europe as alien species: How to make the best of the bad situation?, A.A. Balkema, Rotterdam, Brookfield, 13-22.

Holdich D.M. and Black J., 2007. The spiny-cheek crayfish, Orconectes limosus (Rafinesque, 1817) [Crustacea: Decapoda: Cambaridae], digs into the UK. Aquatic Invasions, 2, 1-16.

Holdich D.M., Haffner P., Noël P., Carral J., Füderer L., Gherardi F., Machino Y., Madec J., Pöckl M., Śmietana P., Taugbøl T. and Vigneux E., 2006. Species files. In: Souty-Grosset C., Holdich D.M., Noël P., Reynolds J.D., Haffner P. (eds.), Atlas of Crayfish in Europe, Publications Scientifiques du MNHN, Paris, 49-130.

Kozák P., Buřič M., Policar T., Hamáčková J., Lepičová A. and Lepič P., 2007. The effect of inter- and intra-specific competition on survival and growth rate of native juvenile noble crayfish Astacus astacus and alien spiny-cheek crayfish Orconectes limosus. Hydrobiologia, 590, 85-94.

Kuhlmann M.L., Badylak S.M. and Carvin E.L., 2008. Testing the differential predation hypothesis for the invasion of rusty crayfish in a stream community: laboratory and field experiments. Freshw. Biol., 53, 113-128.

Lowery R.S., 1988. Growth, Moulting and Reproduction. In: Holdich D.M. and Lowery R.S. (eds.), Freshwater crayfish. Biology, Management and Exploitation, Croom Helm, London, 83-113.

Paglianti A. and Gherardi F., 2004. Combined effecs of temperature and diet on growth and survival of young-of-year crayfish: A comparison between indigenous and invasive species. J. Crustacean Biol., 24, 1, 140-148. 
Petrusek A., Filipová L., Ďuriš Z., Horká I., Kozák P., Policar T., Štambergová M. and Kučera Z., 2006. Distribution of the invasive spiny-cheek crayfish (Orconectes limosus) in the Czech Republic: past and present. Bull. Fr. Pêche Piscic., 380-381, 903-917.

Price J.O. and Payne J.F., 1978. Multiple summer molts in adult Orconectes neglectus chaenodactylus Wiliams. Freshwater Crayfish, 4, 93-104.

Reynolds J.D., 2002. Growth and reproduction. In: Holdich D.M. (ed.), Biology of Freshwater Crayfish, Blackwell Science Ltd., London, 152-191.

Skurdal J. and Taugbøl T., 2002. Astacus. In: Holdich D.M. (ed.), Biology of Freshwater Crayfish, Blackwell Science Ltd., London, 467-510.

Stucki T.P., 2002. Differences in live history of native and introduced crayfish species in Switzerland. Freshwater Crayfish, 13, 463-476. 